\title{
Black Male Students Negotiate Ways of Knowing Themselves During Digital Storytelling
}

\author{
Becky Beucher and Robyn Seglem
}

\begin{abstract}
We explore how valuing Black male students' literacies within academic contexts during multimodal writing can position students' ways of knowing at the center of their learning. This centering requires a repositioning of students' cultural literacies at the core of instruction. Using multiliteracies and Critical Discourse Analysis frameworks, we analyze and share excerpts from conversations with three Black adolescent high school seniors as they composed and reflected upon authoring digital autobiographies for an assignment in their Black Literature class. These reflections illuminate how the students drew on culturally salient texts to share elements of themselves with their peer and teacher audience.
\end{abstract}

\section{Background}

In this paper we explore how valuing racialized students' literacies within academic contexts during multimodal writing can position students' ways of knowing at the center of their learning experience. Centering minoritized students' ways of knowing in school and curricular contexts necessarily requires a repositioning of students' cultural literacies at the center of instruction. This move is of particular importance given how standardized, and therefore homogenized, forms of curriculum and assessment drive decisions around which texts students should be reading, inclusive of text content and form (Lankshear \& Knobel, 2003). This practice perpetuates the erasure of minoritized ways of knowing and all too often marks minority students as failures despite their proficiency with culturally salient literacies (Kirkland, 2013, 2017).

In our discussion, we share excerpts from conversations that Becky had with three Black adolescent high school seniors-Devonte, Malcolm, and Gabriel—as they composed and reflected upon authoring digital autobiographies for an assignment in their English Language Arts class titled, "Black Literature." The excerpts we have selected from these conversations illuminate how the students drew on culturally salient texts (e.g., hip-hop music, quotations from Black leaders; images of their families and friends; sports icons and college mascots) to share elements of themselves with their peer and teacher audience. These conversations concurrently showcase their perspectives about their own agency to control micro and macro identity narratives circulating within the school about who they are. Indeed, as Haddix (2012) has argued, Black male students can "reclaim their literate identities" (p. 129) through storytelling. Through examining these conversations, we discuss how students' ways of knowing themselves were informed by cultural and school discourses related to Black masculinity. 
Teacher-centered instruction is often coupled with the privileging of "learning as 'curricular,' [meaning] that classroom learning proceeds in accordance with a formally imposed/officially sanctioned sequenced curriculum which is founded on texts as information sources" (Lankshear \& Knobel, 2003, p. 6), rather than on students' cultural discourse. Alarmingly, if as Battiste (2013) has argued, "Education has its roots in a patriarchal, Eurocentric society, complicit with multiple forms of oppression of women, sometimes men, children, minorities, and Indigenous peoples" (p. 159), then understanding why Black males continue to have one of the highest rates of school dropout among adolescent youth (Schott Foundation for Public Education, 2015) requires us to ask, as Gloria Ladson-Billings (2006) has argued, not why students of color are failing out of school, but rather how school continues to fail students of color. Indeed, as Kinloch, Burkhard, and Penn (2017) contend, "It is important for literacy practitioners and researchers to interrogate and teach against such beliefs in ways that build on the strength, brilliance, and power of Black lives" (p. 72). In this article, we implore teachers to consider whose knowledge systems are valued through curriculum, instruction, and assignments.

Attending to students' ways of knowing and finding the intersections between those ways of knowing and class curriculum is a powerful technique for valuing student knowledge. We showcase one example of how students' interests can be intricately tied to a school assignment in ways that matter for students. Listening to students' reflections about their choices made while composing their digital autobiographies offers us insight into how they were negotiating these choices in relation to how they understood themselves to be known within the school context by their peers and school staff, teachers, and administration. We align our thinking with other proponents of culturally embedded pedagogies who argue for a complex approach to integrating students' language and literacies in a manner that maintains a focus on creating equitable and humanizing conditions for all students (Gay, 2002; Ladson-Billings, 2017; Paris, 2012; Paris \& Alim, 2015). As Kinloch and colleagues (2017) have argued,

The unreasonable number of Black youth under academic distress, detention, and threat of death result not from their lack of intellect, talent, or composure, but from mainstream society's refusal to either acknowledge Black students' humanity or nurture their developing identities. (p. 71)

Again, we align our approach with Kinloch et al. (2017) who argue that there is a moral imperative for researchers to conduct ongoing studies that "emphasize how an ideological model of literacy is beneficial for understanding adolescent literacies, identities, and counternarratives outside of school" (p. 72), which we are locating within the school context of academic curriculum.

\section{Multiliteracies}

Calls for expanding texts and reading and writing practices in school are not new. More than 20 years ago, the New London Group formed to encourage a more expansive approach to literacy instruction. Their call to action was not an easy one to craft. Indeed, like many English teachers experience today, the conversations between the esteemed researchers who made up the group "were fraught with dialectical tensions" (Garcia, Luke, \& Seglem, 2018, p. 74). As a result, the pedagogy of multiliteracies, a seminal document that continues to influence literacy research today, "was actually an attempt to 
reconcile those different tensions by making the case for immersion in practice, for explicit instruction, for critique and deconstruction, and for social, civic and semiotic action" (p. 76).

Within this new notion of literacy, social interactions, civic engagement, and the inclusion of signs and symbols as important texts were elevated in literacy instruction. As such, multiliteracies were conceptualized as less a study of the tools used to read and compose text, and more as a study of the texts within the context of a larger society. As Allan Luke (2018) reminds us, "literacy matters, but how it matters, for whom, when and where depends upon the rules of exchange in a social field" (p. 4). And in today's tumultuous social and political landscape, Luke (Garcia et al., 2018) prompts us to remember the importance of Freire's (2000) push for students and teachers to read and write the world. For Luke, the very intent of the multiliteracies pedagogy was a focus on pedagogical design as "an agentive bridge between convention and innovation, between the canonical and the new, between reproduction and creativity" (Garcia et al., 2018, p. 75). Through this lens, then, multiliteracies prompt teachers to preserve and privilege culturally salient texts, to use literacy to build community rather than tear it down, and to engage students in civic action. Advocates for integrating hip-hop music and culture in school curriculum have been making similar arguments about the civic and academic benefits for youth of color. We draw on hip-hop music as a way of knowing because of how Malcolm, Gabriel, and Devonte drew on musical discourse when composing their digital autobiographies.

\section{Hip-Hop Music and Ways of Knowing}

Hip-hop music began as a multimodal construction of sounds, beats, rhythms, and narrative authored by Black revolutionaries who, through their music, were concurrently functioning as poets and political leaders. As the music industry bent toward White male adolescents' taste preferences (Rose, 2008), American mainstream cultures' exposure to hip-hop music as entertainment was largely shaped through the image of popular gangsta rap, a genre rife with misogyny, glorification of guns, violence, sex, drugs, and other related illicit activities. Recently, there has been a resurgence of politicized hip-hop on the mainstream stage, epitomized by Kendrick Lamar being awarded the Pulitzer Prize for his album DAMN (Lamar, 2017). As modern technologies afford widespread access to music files with opportunities for remixing and composing with hip-hop music as a modern form of sampling, educators cannot afford to ignore the influence hip-hop music has on shaping how youth are making sense of themselves and how they are speaking back to these discourses.

Scholars have argued extensively for harnessing African-American youth hip-hop culture in the classroom (Alim \& Haupt, 2017; Emdin, 2017; Mahiri, 1996, 1998, 2006; Morrell \& Duncan-Andrade, 2002; Paris, $\&$ Alim, 2014). Hip-hop music has many affordances for education, inclusive of promoting urban youth's ways of knowing (Emdin, 2017), and for developing all students' aptitude in reading and communicating through multiple linguistic registers and discourses. Such an ability enables students to critically interrogate power relations emergent across texts (Gee, 2014). Indeed, "the influence of rap as a voice of resistance for urban youth proliferates through artists that endeavor to bring an accurate yet critical depiction of the urban situation to a hip-hop generation" (Morrell, 2002, p. 10). 
Moreover, Morrell and Duncan-Andrade (2002) have argued that within the English Language Arts classroom, hip-hop, a culturally salient genre-with merit in its own right—could, "serve as a bridge between urban cultures and the literary canon" (p. 90). Hip-hop, they explained, was ideal for inspiring discussions that could lead to critical analysis and composition of texts-both expository and poetic. For youth, and particularly for youth identifying with urban hip-hop culture, studying hip-hop music through a critical lens can offer students access to counter narratives and avenues for powerful selfexpression within school contexts. However, as we learn from the three students about how they found their own ways of knowing themselves in hip-hop music, we exercise and advocate for caution here.

Kirkland (2013) warns about reading too deeply into hip-hop music's lyrics to know Black male's lives. He explains, "There has been a lot written about Black males and rap, indeed romanticizing the escapade as the universal narrative where modern Black male stories reside..." (p. 34). In seeking to learn with students about the role that music (and other texts) played in how they came to know themselves, we reject a position that might view students' selected hip-hop songs as wholesale reflections of their life stories, experiences, or subjectivity. Rather, we understand these songs, and the students' reflections upon these songs, as offering traces for how the students understood themselves in a world that shackles young Black men's subjectivity to narratives saturated with stories of violence, criminality, and academic failure.

\section{Methods}

Over the course of a school semester, Becky, a White female literacy researcher and Devonte, Malcolm, and Gabriel, three Black male high school students, met and discussed the digital media project (DMP) during class time, students' free periods, before and after school, and during lunch time. While Robyn did not meet the students in person, she came to know them through examining their DMPs and through the case studies Becky composed. Over the semester, Becky collected audio recordings of students talking to her, themselves, their peers, and their teacher about their digital composition choices as they composed digital autobiographies for a high school English language arts project. Throughout, students reflected on the salience of hip-hop music in their lives as they wove the songs they listened to on repeat into their iMovie projects. These cases highlight how students-whose in-school academic success (e.g., writing essays, taking multiple choice/essay tests about literature) typically ranged from excelling to failure-each demonstrated a sophisticated capacity for navigating both critical and academic literacies during digital storytelling. Our analysis illustrates how curriculum that invites students to draw upon their multiple ways of knowing, enables students to "develop the capacity to speak up, to negotiate, and to be able to engage critically with the conditions of their working lives" (New London Group, 1996, p. 67).

In this article, we share three excerpts from larger case studies. We drew on Critical Discourse Analysis (CDA) (Luke, 1995) in our approach to exploring students' articulated ways of knowing themselves in

relation to their modal choices and micro and macro discourses that they were measuring their sense of self in relation to. Through CDA, we revealed and examined the larger "storylines" complexly embedded 
in each student's unequal and consequential access to various forms of power, in which their more explicit narratives are situated.

\section{Participants}

Devonte, Malcolm, and Gabriel were high school seniors in the class Black Literature taught by Dr. Kira Buchannan at Regional High School in the fall of 2012. Kira and Becky created the Digital Media Project, a digital autobiographical writing assignment that required students to combine pictures, words, and music in a coherent narrative about their lives. Each of the cases below showcase how the three students engaged in multiliteracies practices through this project that allowed them to speak up, negotiate, and engage in critical thinking, key elements identified by the New London Group (1996) in their vision of future literacy practices.

Speaking Up: "So, I keep it on lock. But...I feel like it's necessary to tell you" Devonte. During their time together, Devonte frequently shared that he felt grossly misunderstood by his peers. Because of these presumed misunderstandings, he expressed reticence for sharing details of his life that he believed his peers would hold against him. Yet, he simultaneously expressed a desire to disrupt his peers' perceptions of him, even as he himself struggled to liberate his present self from his past. He worked through these tensions as he conceptualized, composed, and reflected upon his approach to composing his digital story.

Devonte identified the theme of his digital story as "struggle," explaining, "Mine's like, kind [of] like a struggle theme." He continued, "Like coming from nothing and trying to be something type thing." He later shared that as a young child between the ages of 10 to 15 , he had to sell drugs to help his family pay their rent. Devonte was reticent to share these details with his peers, explaining, "I let very few people into my life because I don't want to be judged." He explained that he generally keeps these details, "on lock;" yet, after making this statement, he turned to Becky and said, "But I feel comfortable with you, telling you about it because I feel like it's necessary to tell you."

Devonte found a safe avenue for sharing through his modal choices. By situating his early life of struggle alongside other Black males like the Notorious B.I.G. and Meek Mills, hip-hop artists who rapped about coming up through struggle, Devonte was able to allude to his early life of struggle without publicly naming that struggle as his own. This allusion emerged when he discussed his music choices with Becky, pointing to how Meek Mills' rap describes how he had to hustle. "That's what I had to do, so it's all the same thing." As "Dreams and Nightmares" played in the background, "Ain't this what they been waiting for?" Devonte reflected on his past life that, for him, mirrored what Mill rapped about in "Dreams and Nightmares." "So, it's been a little ra. It's been rough from the beginning with what me and my brother had to do, but it's all good...I mean it all comes to play right now. So it's all good." Here, Devonte indexed time in reference to the struggle as something experienced in the past; he also used the word "beginning" in relation to talking about this struggle, as though as far back as he could remember, his life had been wrought with struggle. 
Meek Mills was not the only rapper he referenced in this exchange. "It's all good" mirrored a phrase in refrain of the song, "Juicy," by Notorious B.I.G. that Devonte also included in his digital story. This song held special significance to him because his mother had played Juicy in their home when she brought him home from the hospital following his birth. Whether intentional or not, Devonte drew upon the language and discourse in these hip-hop songs as he engaged multiple modes of expression, both in conversations about his digital story and in his digital story composition.

Devonte also situated his ways of knowing himself alongside the words of the renowned German philosopher Friedrich Nietzsche. He expressed to Becky that these words resonated deeply with him. On the frame (see Figure 1), the text was set against a black backdrop and was written in white, aside from the word "overwhelmed," which was layered with color; the top of each letter began in red that faded to green towards the bottom of each word.

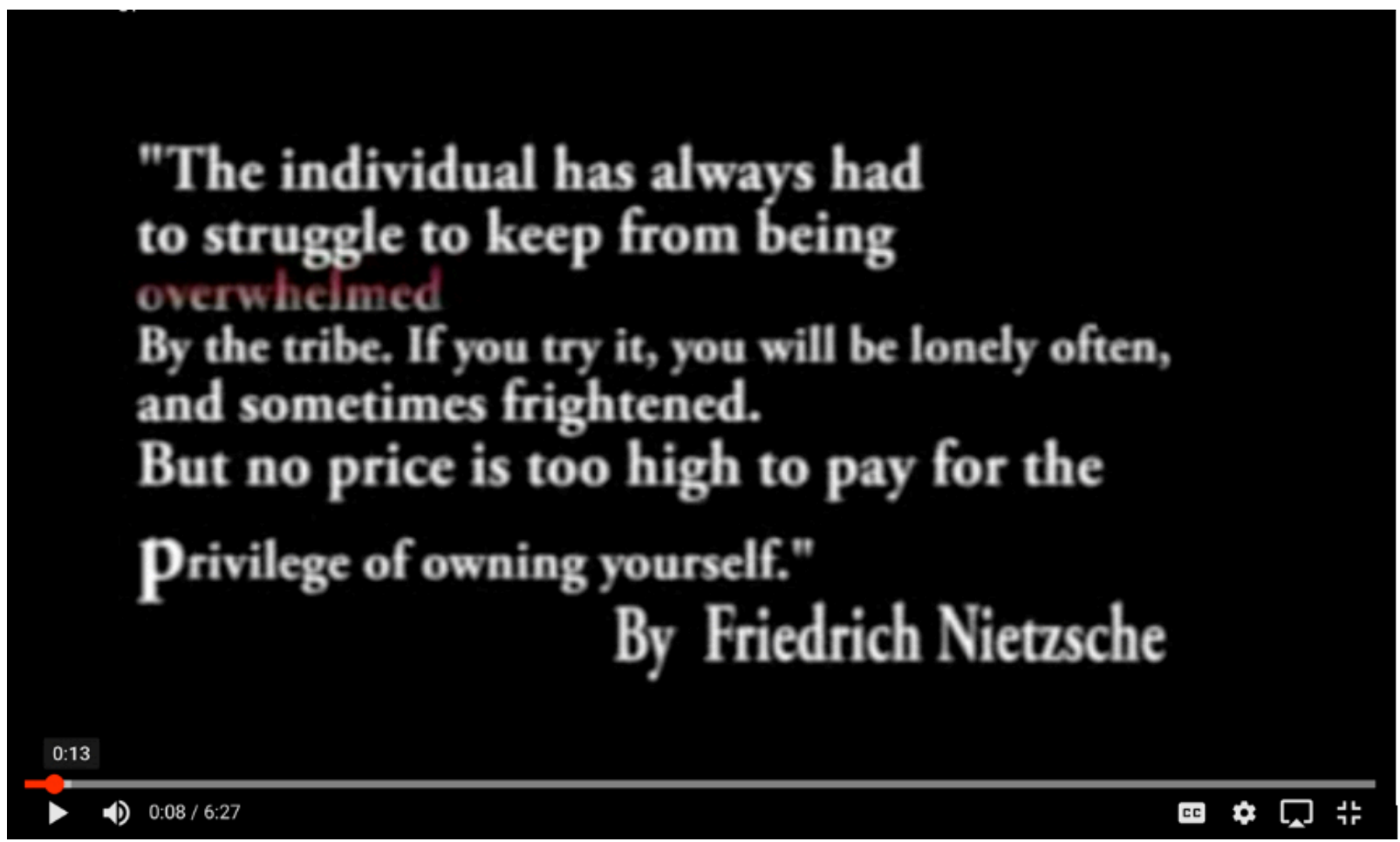

Fig. 1: Devonte's Digital Media Project, Nietzsche quotation.

As these words appeared on the screen, lyrics from "Juicy" emerged from the computer speakers. The voice of the Notorious B.I.G. finished the opening lyric, "I would never amount to nothin', to all the people that lived above the buildings I was hustling in front of that called [the police on me]."

The juxtaposition of the song lyrics with the Nietzsche quotation seemed to capture the essence of the tensions Devonte struggled between in his efforts to claim his own narrative.

"Hustling" was something that Devonte had admittedly done in his life, and as he composed his digital story, he struggled between telling people about that life and telling a different story. He recalled 
experiences where people made unfair assumptions about him being mean when he viewed himself as direct and honest. He also named "judgment," or desire to circumvent judgment, as reasons for not sharing his own hustling experiences with the class. Devonte's modal choices reflected the ways he was thinking about these struggles in relation to his own life as well as how he was drawing connections to how others had articulated living with hardship.

Further, his discussion with Becky around his reasons for selecting the Nietzsche quote underscores how deliberate his choices were in composing his narrative:

Devonte: It just means a lot. This one like stuck to me the most over all the ones I read.

Becky: That last line, "the price is too high for the privilege of owning yourself."

Devonte: Exactly. That's the one that actually like stuck to me.

Becky: Yeah.

Devonte: If I, cuz see, uh, can I start off with something like that?

Becky: Yeah.

Devonte: That, that honestly like pulls you in.

Asking Becky if he could start his DMP in this manner implied that perhaps he held in mind their earlier conversation about how good writers start narratives as he selected this quotation. Regardless, that quotation "stuck" to him among the others. Devonte explained that he liked the quotation because it had the effect of "pull[ing] you in." Using the pronoun "you" rather than "me" suggests that he may have been thinking about a provocative opening for his audience, or perhaps he just meant that the quote resonated with him.

Ultimately, Devonte's experience with materializing a struggle storyline allowed him to negotiate what he revealed about his own personal experiences living as a Black man growing up in poverty in the United States in a narrative that would be publicly shared with a peer audience that he expected judgment from. While Devonte engaged a socially critical discourse in his DMP wherein he implied his understanding that his struggle was shared and endured by many Black men in the United States, he purposely withheld sharing the details of his personal life struggles from most people to circumvent this expected judgment.

In early conversations with Becky, he explained how the music allowed him to express the struggle he had endured as a young Black man. For Devonte, the music functioned as a source of solidarity and as a shield. Ultimately, the choice to tell the details of his life and struggle remained his, and music allowed him to speak up and share traces of his life without having to take others' judgment on alone. It is important to note that Becky made careful efforts to not judge Devonte and to instead serve as a critical witness (Dutro, 2013) receiving and holding his stories with gentle care. This approach to listening resonated with Devonte who expressed both his willingness and his desire to divulge details of his painful memories during their conversations, creating a space for him to use literacy as a way to speak up about ways he knows about life.

Negotiating: “...Like, I'm not even sure you get what he's saying” Malcolm. Malcolm wrote his DMP amid contemplating an uncertain future and was negotiating several discourses related to how he and 
others were defining him. Following several weeks of living displaced from his home and, as a result, missing a significant amount of school, he had returned to failing grades in several of his classes, grades he was admittedly dismayed about. He had concurrently been accused of stealing and selling school laptops, which he contested and was waiting for his pending court date. In addition, he had narrowly avoided being the victim of a drive-by shooting over the previous weekend. He talked about all these upheavals as he composed his DMP.

Many of the words that Malcolm wrote across the images in his DMP were taken from a poem he had written during class in Black Lit. He read this poem aloud after school one day. The poem below is composed from the audio transcript and includes his compositional pauses.

Look me in the eyes; tell me what you see. I was losing out on life due to my selfish needs. Never understood why many [pause]. Ho, a, never understood why. Why I had so many re-[pause]. Why I had so many responsibilities at what building character is. Is what I didn't see. So I set out on this mission to destruction and hustling. See Moms wanted_-[pause]. See_- [pause]. Oh yeah. And see Moms wanted the best. Kept me away from the set. Even tried to move me out to jet. Everyday I ha-[pause]. I was training like it was my last breath forcing these visions on my path NFL dreams. But, broad day struck with my blue flag.

The poem constructs a humble, reflective, and passionate version of Malcolm. Yet, in much of his DMP, Malcolm is "Mo-Stacks," the star of Malcolm's DMP. In this video, his clothes are labeled with words like "fresh to death" (see Figure 2); he has a beautiful girlfriend and supportive mother, whom he loves; he has a crew; and he plays football and is looked up to by children. He also included elements of his written words throughout his DMP. Yet, his negotiations came in the form of him weighing how his audience would interpret the content.

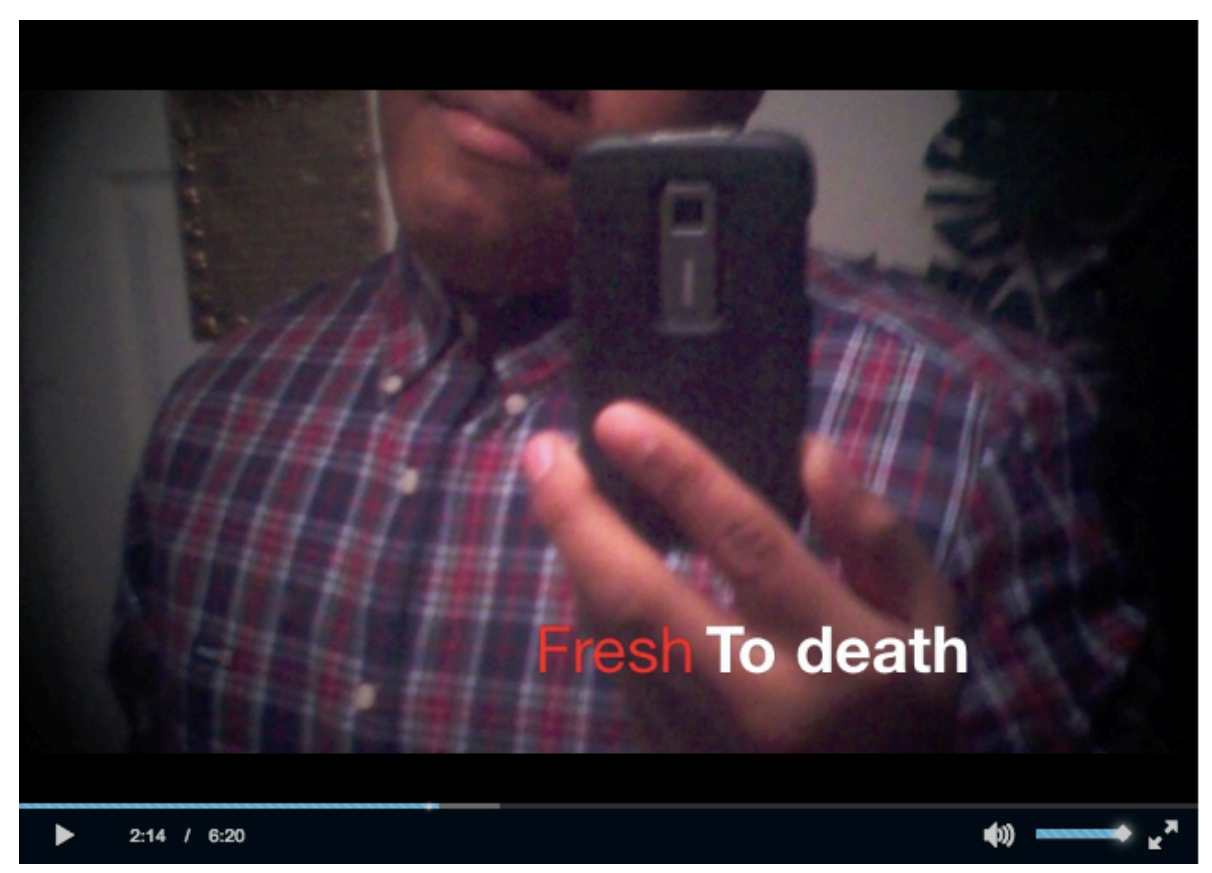

Fig. 2: Malcolm selfie, "Fresh to Death." 
Malcolm shared that the music in his DMP revealed "a lot of stuff" about himself that he could not explicitly say. Referring to another song he ultimately did not keep in his final DMP, Malcolm explained, "...if you listen to my song, it literally talks about me...Literally, everything that he's saying." Following his general explanation of the parallels, he asked Becky, as he often did, whether she understood: "You know what I'm saying? Like I'm not even sure you get what he's saying."

He opened a conversation with Becky on his own initiative, wishing to explain that his song "literally" talks about him and told his story. Yet, he assumed that his audience (Becky in this instance) would not understand the meaning of the words, rendering his story safely hidden within seemingly incomprehensible lyrics. It is also perhaps telling that he chose not to include this song that he felt was "literally" about his life on account of his sense that his audience might misunderstand and judge him.

He mentioned several times he did not intend for his words to be understood, nor did he expect people to understand them. His reflections exemplified a felt isolation that Malcolm expressed frequently. In this, he raised questions about the assumptions we are at risk of making about others if we fail to pursue learning more about their perspectives and experiences.

Perhaps in response to these discourses that conflicted with his own sense of self, for his final DMP, Malcolm chose to write about a person amid success. Meek Mill's "Realest Shit You Ever Seen," is a song largely about the protagonist being powerful and obscenely wealthy to the extent that he can burn money. Malcolm's self-characterization in relation to a successful, powerful, defiant, modern rap artist enabled his artistic control over the story of himself, a person whom he believed was not understood in his daily life. Malcolm knew that music had the capacity to tell his life story, but rather than selecting the song that told the story of his life, he chose the song that told a story of success; thereby, interweaving latent success in his life narrative.

Malcolm further confronted the discourses engaged by people in his life who cast him as a criminal and failure with a provocative close-up image of his face through which he invited his audience to look him in the eyes when they cast their judgment. In this frame (see Figure 3), Malcolm stared intensely at the camera, eyes squinted, eyebrows raised, jaw clenched, lips parted, and teeth showing. He wore a black doo rag on his head, a plaid shirt, and a black jacket. As the music played, the camera panned out showing more of Malcolm's face. Meek Mill rapped, "Look me in the eyes; tell me what you see!" Mill's voice echoed, "Realest shit you ever seen. Realest shit you ever seen." Immediately after the image appeared, white text moved in rapidly across the screen stopping at Malcolm's pictured eye-line. The text, written in white, read, "Look Me In My Eyes Tell me what You see!" 


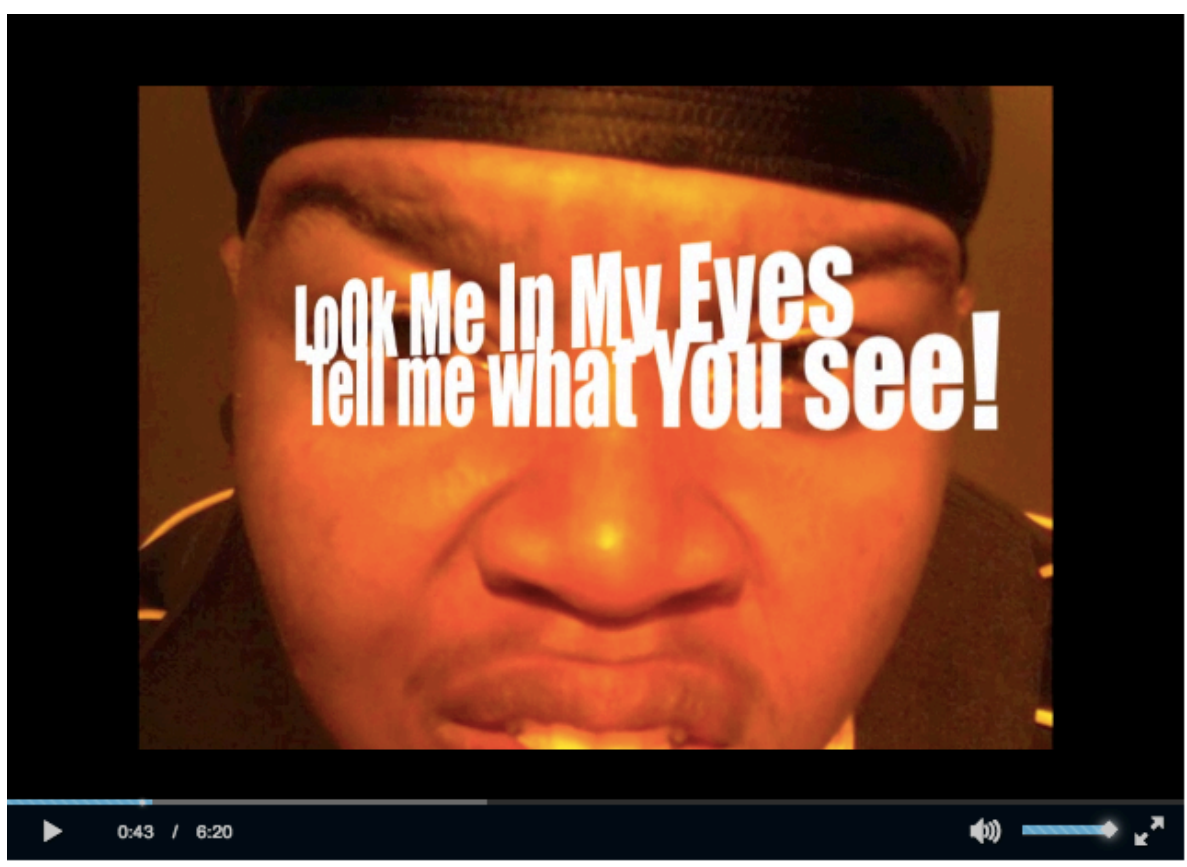

Fig. 3: Malcolm, Look me in my eyes. Tell me what you see.

The lyrics playing during this slide-Mill's words, "Realest shit you ever seen. Realest shit you ever seen" - seemed to cast Malcolm's invitation, "Look me in my eyes. Tell me what you see," as a rhetorical question. Mill's lyric provided an answer to what one should see when looking Malcolm in the eyes. The exclamation point following the words, "Look me in the eyes; tell me what you see" indicated how this line functioned as an imperative. Juxtaposing the fierce look captured in the image of Malcolm underscored the connection between the imperative and the music overlaying the image and words. Yet, this slide followed a video introducing Malcolm himself as a fictionalized character, Mo-Stacks. In this way, Malcolm's DMP constructed an elusive self-representation that defied categories of his "real" self and the fiction of an imagined future.

While he was asking the audience to see him, he was literally not being Malcolm; rather he was presenting future, fictionalized Malcolm. He offered an intimate invitation for the audience to look into his eyes and see what was there; yet, he held them far away from the self he allowed them to know. Interestingly, in the following slides, Mo-Stacks seemed to disappear while images of the high school Malcolm encompassed a majority of his narrative up to the final video that concluded his DMP. His multifaceted presentation of self, combined with how he negotiated this sharing, reflects the complex approach Malcolm continued to take when constructing his subjectivities in relation to his varying audiences.

Critical: “...You'd Be Like, What?” Gabriel. Like Devonte and Malcolm, Gabriel, too, consciously performed the complex task of managing audiences (teachers, researcher, peers, family, football fans) across in-and-out-of-school spaces. Reading through texts, he demonstrates his understanding of how the public nature of the DMP meant his choices must be made in relation to who he was telling the story for. 
Rather than viewing the DMP as personal narrative that might divulge intimate details of his life, Gabriel instead described the DMP as a "fancy little project" and his expressed goal was to earn an "A." For this reason, Gabriel scheduled daily meetings with Becky to work collaboratively on his DMP. For Gabriel, earning an " $A$ " primarily meant composing a project that was appropriate for his school-based audience.

Gabriel's approach to engaging critical literacies during digital composition is evidenced when he pushed back against Becky's encouragement that he select personally salient music. Becky asked Gabriel what music he listened to when he was happy, as he had expressed a desire to strike a "happy tone" in his project. Immediately, applying his sense of his DMP school audience, Gabriel said, "the songs I listen to are dumb. But I like 'em. Like 2 Chainz and stuff like that." Becky reminded him that this was his movie, and he should include what he liked. Laughing, he implied that because she was a part of his audience, her opinion would matter. He elaborated, "If you heard the song you'd be like, what?" They laughed together; he continued, "It's called crack." Gabriel played the first part of the song to prove his point: "Started from the trap now I rap. No matter where I'm at I got crack." The song ended, and Gabriel relayed, "You see why I don't want to use it? That's actually my game song. I play it before every game." Here, Gabriel succinctly explained why one of his favorite songs, a song about a rap star who used to sell drugs but who now makes his income rapping, did not belong in his personal digital narrative account of whom the story would be shared with-in this case, he kept his teachers in mind. In making this statement, he also indexed his awareness of how context mattered for song choice-a song that was appropriate for the football field did not belong in the classroom.

Later, Gabriel worked to achieve a melancholy effect when selecting the most appropriate song to reflect his sentiment about his mother, whom he had not seen in person for 10 years. Gabriel instantly knew that he wanted the song "Battle Scars" by rap artist Lupe Fiasco to play on the screen as his mother's image appeared. Becky and Gabriel listened to the song together. As Lupe Fiasco sang, "...These battle scars don't look like they're fading, don't look like they're ever going away—" Gabriel stopped the song and said, "See right there that part." He continued,

Like what he said, like even though all of these things I'm doing like he said, it's almost like the sadness is not going away because I'm no closer to my mom than what I was when I left her, you know?

Gabriel felt compelled to include a song with lyrics that articulated the emotions he rarely verbalized himself and that he felt guarded about.

When Gabriel selected the picture of his mother, he called her his "heart and soul," underscoring the centrality of her role in his life. The song emphasized the pain he felt because she could not share in his accomplishments as they lived half a world away from one another. He explained, "Everything I do is for my mom," elaborating to Becky about his mother's importance to him and the pain represented in that song. However, he did not wish to share those details with his peers. He explained: 
I just don't care for them to know. That's just how I feel like. Because we are going to do this, present is, and it's going to be over with. They don't need to know my whole, like life story or what not. Like, I don't know. Cuz watch, when we see other people's stuff.... It's not gonna have all [of this information about people]. And this is like, this is kind of like my how do you call it? Sensitive side?

Gabriel expressed sensitivities to how his peers might interpret his emotional self as he considered songs for his DMP. In response to Becky's reaction and in further explaining why he edited out the explanation he originally gave Becky about his mother, Gabriel expressed that he did not want to invite people's sympathies or pity with his DMP. He said, "I don't want to be looked at like [I'm] this sad kid walking around." He continued, "I don't want my whole presentation to be like this, this sad story. Like there is no happiness in my life."

Gabriel also expressed concerns about disrupting gender norms related to masculinity. For this reason, he hesitated to include the song "Diamonds" by Rhianna, explaining, "I don't know how people would look at it, like oh he's using a song by a girl, or what the heck?" Becky's reading of his hesitation at the time was that he feared his masculinity might be called into question in using this song, and she responded accordingly in telling him that she expected that his masculinity would remain unchallenged should he include that song, which reinforced the gender and heteronormative discourses Gabriel was negotiating as he considered what it meant for him to select a "song by a girl." Ultimately, Gabriel decided to have this song play as images of his high school senior photograph, an image of him with his partner's arms wrapped around his chest, and professionally taken images of himself playing quarterback on the football field, played across the screen (see Figure 4). This choice of music demonstrated his efforts at disrupting dominant gender norms related to his subjectivity.

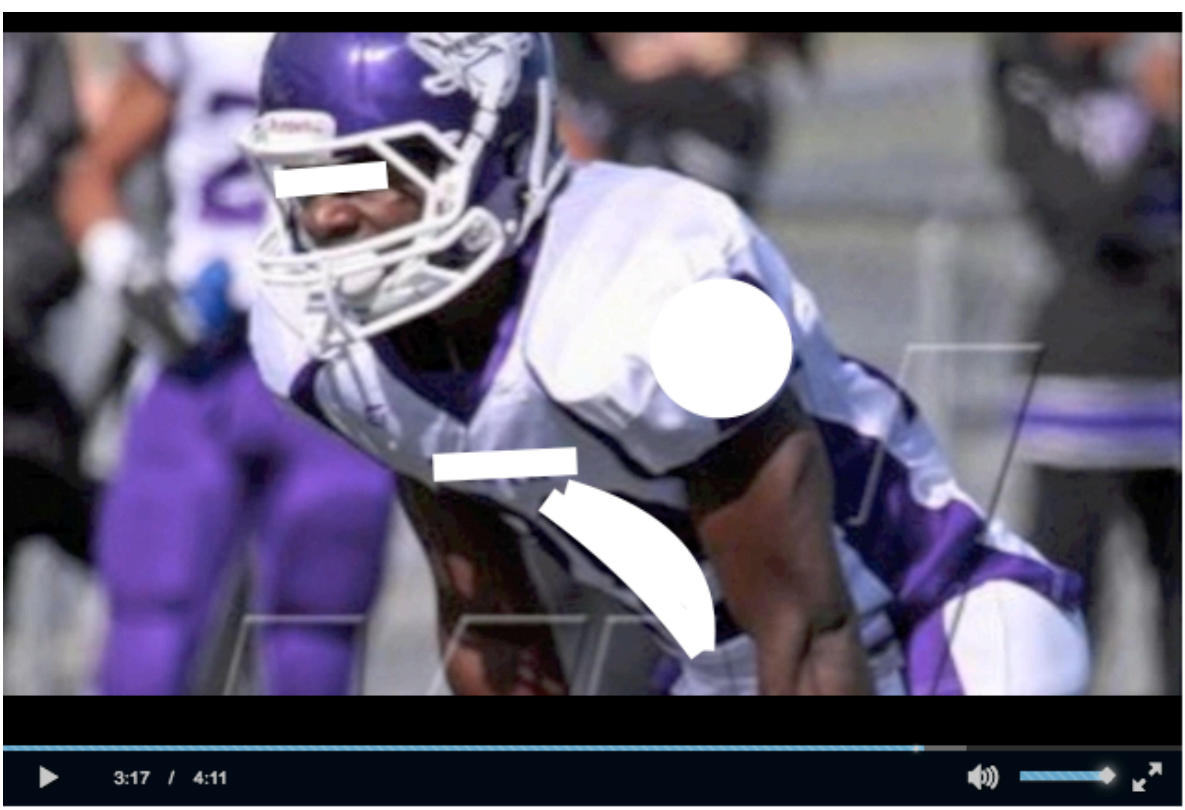

Fig. 4: Gabriel on the football field. 
Gabriel's case complicates how teachers can understand students' motivations for selecting music that they claim speaks for them. Gabriel closely read and considered the music lyrics he wanted to include for a specific desired effect on audience. His approach reflects a complex intertwining of traditional, multimodal, and critical literacies where each became prominent according to author purpose and in which no single form dictated the overall story design.

\section{Privileging Student Cultural Discourses as Ways of Knowing}

Listening to students' reflections on their composition processes reveals how Malcolm, Devonte, and Gabriel weighed various discourses between how they and others knew them as each wrote about himself. Devonte used the digital storytelling processes to speak up and voice his position on urban poverty and to reflect on his experiences living in those conditions. He found in hip-hop music and philosophy a certain perception of his life that resonated with his values and projected life goals. Malcolm's digital story process reflected the ways in which he was negotiating multiple discourses influencing his way of knowing himself. Malcolm contended with labels like "failure" and "criminal" in his daily life. He began his digital story with a powerful confrontation inviting the audience to judge him on his terms. Gabriel's case demonstrates how he engaged analytical and critical literacies while composing his digital story. He considered how his peers and teachers would interpret his use of hip-hop and other songs performed by male and female artists. Throughout the school semester, students were also negotiating these discourses through spoken conversations, pen and paper writing, listening to music, reading other's published words, looking at images, and through remembering, reflecting, and projecting to future selves. Considering Devonte, Malcolm, and Gabriel's processes, we offer the following implications from these cases.

Given the sensitivities evidenced in each student-author's processes through which they negotiated the varying versions of themselves that they might share with others, we contend that publicly displaying personal narratives asks students to be vulnerable with one another, often in uncomfortable ways. Knowing that students are negotiating how others see them, teachers should offer students multiple avenues for divulging personal information about themselves and acknowledge that a part of that process involves considering whom one represents oneself as. Regarding assessment, we question the value of awarding points to this kind of personal writing. Each student used multiple literacies throughout their process, some of which lent themselves better for different writing purposes, and we are concerned that awarding points related to students meeting set criteria for composition might interrupt the rich processes students engage as they weigh and consider audience in relation to autobiographical storytelling. We encourage teachers to include multiple forms of writing as options for students' composition processes. Furthermore, students might benefit from having conversations with the teacher and with peers of their choosing about the process around what each author is considering and weighing through their decision-making processes. 
Ultimately, as we consider students' ways of knowing and the experiences that influence how they and others come to know them, we must simultaneously consider which texts should be privileged in their educational experiences. Thus, this article has engaged a conversation about consumption and production, about which texts adolescents are interpreting and constructing both inside and outside of school, and, how they are weighing these narratives as they make sense of themselves. The high incidence of incarceration, lethal profiling, and the low graduation rates of male youth of color underscore the crucial importance for educators to design curriculum that affirms Black male subjectivities and literacies within school contexts. We have argued that school curriculum must account for youth's out-of-school literacy practices and interests in in-school spaces, not simply to sanction these literacies, but to invite direct and meaningful engagement with the texts that students are drawing from to make sense of their lives and their positioning in the world.

\section{References}

Alim, H. S., \& Haupt, A. (2017). Reviving soul(s) with Afrikaaps: Hip hop as culturally sustaining pedagogy in south Africa. In D. Paris and H. S. Alim (Eds.), Culturally sustaining pedagogies: Teaching and learning for justice in a changing world (pp. 157-174). New York, NY: Teachers College Press.

Battiste, M. (2013). Decolonizing education: Nourishing the learning spirit. Saskatoon, Canada: Purich Publishing.

Dutro, E. (2013). Towards a pedagogy of the incomprehensible: Trauma and the imperative of critical witness in literacy classrooms. Pedagogies: An International Journal, 8(4), 301-315.

Emdin, C. (2017). For white folks who teach in the hood ... and the rest of $y^{\prime}$ all too: Reality pedagogy and urban education. Boston, MA: Beacon Press.

Freire, P. (2000). Pedagogy of the oppressed. New York, NY: Continuum.

Garcia, A., Luke, A., \& Seglem, R. (2018). Looking at the next 20 years of multiliteracies:

A discussion with Allan Luke. Theory Into Practice, 57(1), 72-78.

Gay, G. (2002). Preparing for culturally responsive teaching. Journal of Teaching Education, 53(2), $106-116$.

Gee, J. P. (2014). An introduction to discourse analysis: Theory and method. New York, NY: Routledge.

Haddix, M. M. (2012). Reclaiming and rebuilding the writer identities of black adolescent males. In D. E. Alvermann \& K. A. Hinchman (Eds.), Reconceptualizing the literacies in adolescents' lives: Bridging the everyday/academic divide (pp. 112-131). New York, NY: Routledge.

Kinloch, V., Burkhard, T., \& Penn, C. (2017). Beyond school: Examining the out-of-school literacies and counternarratives of adolescent learners. In K. A. Hinchman \& D. A. Appleman (Eds.), Adolescent literacies: A handbook of practice-based research (pp. 61-77). New York, NY: Guilford Press.

Kirkland, D. E. (2013). A search past silence: The literacy of young Black men. New York, NY: Teachers College Press. 
Kirkland, D. (2017). Beyond the dream: Critical perspectives on black textual expressivities... Between the world and me. English Journal, 106(4), 14-18.

Ladson-Billings, G. (2006). From the achievement gap to the education debt: Understanding achievement in U.S. schools. Educational Researcher, 35(7), 3-12.

Ladson-Billings, G. (2017). The r(e)volution will not be standardized: Teacher education, hip hop pedagogy, and culturally relevant pedagogy 2.0. In D. Paris and H. S. Alim (Eds.), Culturally sustaining pedagogies: Teaching and learning for justice in a changing world (pp. 141-156). New York, NY: Teachers College Press.

Lamar, K. (2017, April 14). DAMN. [Video File]. Retrieved from http://www.pulitzer.org/winners/kendrick-lamar.

Lankshear, C., \& Knobel, M. (2003). New literacies, changing knowledge and the classroom. Buckingham, UK: Open University Press.

Luke, A. (1995). Text and discourse in education: An introduction to critical discourse analysis. In M. Apple (Ed.), Review of Research in Education, (21), 3-48. Washington, D.C. American Educational Research Association.

Luke, A. (2018). Critical literacy, schooling, and social justice: The selected works of Allan Luke. New York, NY: Routledge.

Mahiri, J. (1996). Writing, rap, and representation: Problematic links between text and experience. In P. Mortensen and G. Kirsch (Eds.), Ethics and representation in qualitative studies of literacy (pp. 228-240). Urbana, IL: National Council of Teachers of English.

Mahiri, J. (1998). Streets to schools: African American youth culture and the classroom. The Clearing House, 71(6), 335-338.

Mahiri, J. (2006). Digital DJ-ing: Rhythms of learning in an urban school. Language Arts, 84(1), 55-62.

Morrell, E. (2002). Toward a critical pedagogy of popular culture: Literacy development among urban youth. Journal of Adolescent \& Adult Literacy, 46(1), 72-77.

Morrell, E., \& Duncan-Andrade, J. (2002). Promoting academic literacy with urban youth through engaging hip-hop culture. English Journal, 88-92.

New London Group. (1996). A pedagogy of multiliteracies: Designing social futures. Harvard Educational Review, 66(1), 60-92.

Paris, D. (2012). Culturally sustaining pedagogy: A needed change in stance, terminology, and practice. Educational Researcher, 41(3), 93-97.

Paris, D., \& Alim, H. S. (2014). What are we seeking to sustain through culturally sustaining pedagogy? A loving critique forward. Harvard Educational Review, 84(1), 85-100.

Rose, T. (2008). The hip hop wars: What we talk about when we talk about hip hop--and why it matters. New York, NY: Civitas Books.

Schott Foundation for Public Education. (2015). Black lives matter: The Schott 50 state report on public education and black males. Retrieved from http://schottfoundation.org/resources/black-lives-matterschott-50-state-report-public-education-and-black-males. 


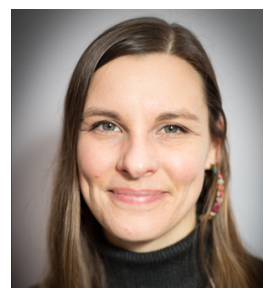

Becky Beucher is an Assistant Professor of Secondary Literacy in the School of Teaching at Illinois State University. Her research interests include investigating racialized adolescent youths' multiliteracy practices and engaged identity discourses in secondary school contexts. She uses poststructural and decolonial feminist theories to explore youth's storying processes during digital composition. She draws on findings from these explorations to develop critically informed multiliteracies curriculum with practicing teachers. She taught English and Language Arts for six years in middle school and high school public, private, and charter school classrooms.

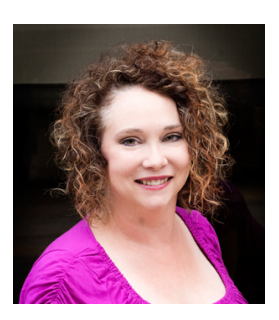

Robyn Seglem is an Associate Professor in the School of Teaching and Learning at Illinois State University, teaching content literacy, language arts methods, and educational technology. She has served as a co-director of the Flint Hills Writing Project, an affiliate with the National Writing Project, and is a nationally boardcertified teacher. Robyn worked with a team of ELA educators to recently revise and update the standards for English and Language Arts for the National Board for Professional Teaching Standards. She taught language arts for nine years in the middle school and high school classroom. 